December 2008

\title{
The Greek Relief Committee: America's Response to the Greek Genocide (A Research Note)
}

Nikolaos Hlamides

Follow this and additional works at: https://digitalcommons.usf.edu/gsp

\section{Recommended Citation}

Hlamides, Nikolaos (2008) "The Greek Relief Committee: America's Response to the Greek Genocide (A Research Note)," Genocide Studies and Prevention: An International Journal: Vol. 3: Iss. 3: Article 9. Available at: https://digitalcommons.usf.edu/gsp/vol3/iss3/9

This Articles is brought to you for free and open access by the Open Access Journals at Digital Commons @ University of South Florida. It has been accepted for inclusion in Genocide Studies and Prevention: An International Journal by an authorized editor of Digital Commons @ University of South Florida. For more information, please contact digitalcommons@usf.edu. 


\title{
The Greek Relief Committee: America's Response to the Greek Genocide (A Research Note)
}

\author{
Nikolaos Hlamides \\ London, UK
}

In studies of the various relief efforts launched in response to the fate of Ottoman Christian minorities in the early twentieth century, much attention is given to the American Committee for Armenian and Syrian Relief and, in particular, to its successors under different names, especially the Near East Relief. The role of other American-based aid organizations has been largely overlooked. This paper serves as an introduction to the Greek Relief Committee, a New York City-based organization that worked alongside other relief organizations from 1917 until 1921, administering aid to the Ottoman Greek population.

Keywords: relief organization, Greek Genocide, American philanthropy

The Relief Committee for Greeks of Asia Minor, or Greek Relief Committee (GRC), was an American relief organization formed during World War I in response to the genocide of Greeks in the Ottoman Empire. Its principal aim was to alleviate the suffering of the Ottoman Greek minority. From 1917 until July 1921, this New Yorkbased organization functioned alongside the American Committee for Armenian and Syrian Relief (ACASR) - which in 1918 was renamed the American Committee for Relief in the Near East (ACRNE) and eventually adopted the name Near East Relief (NER) - in distributing aid to the Greek and other Christian minorities of Ottoman Turkey. The GRC, "organized for non-political and purely humanitarian purposes," had offices at 1 Madison Avenue as well as at 1115 Broadway in New York. ${ }^{1}$

The GRC assisted Ottoman Greeks in Thrace and Asia Minor through centers of relief established at various points. ${ }^{2}$ Foreign consuls, missionaries, and relief workers were the distributors of relief on the ground. ${ }^{3}$ The committee used the same channels as the ACASR, which remained open in spite of the war. ${ }^{4}$ Similarly, the committee assisted refugees from Turkey in Greece and the islands through the American Legation at Athens and the American Consulate at Salonika, in cooperation with the various Greek organizations there. ${ }^{5}$

Until October 1917, the GRC had "been working quietly under difficult circumstances without much publicity." ${ }^{6}$ The committee's chairman was Frank Watterson Jackson (1874-1955), an attorney and former American consul at Patras, Greece. It was only in a 17 October 1917 statement that Jackson brought the fate of the Ottoman Greeks to America's attention: ${ }^{7}$

The story of the Greek deportation is not yet generally known... There were some two or three million Greeks in Asia Minor at the outbreak of the war in 1914, subject to Turkish rule. According to the latest reliable and authoritative accounts some seven to eight hundred thousand have been deported, mainly from the coast regions into the interior of Asia Minor.... Along with the Armenians most of the Greeks of the Marmora regions and Thrace have been deported on the pretext that they gave

Nikolaos Hlamides, "The Greek Relief Committee: America's Response to the Greek Genocide," Genocide Studies and Prevention 3, 3 (December 2008): 375-383. (C) 2008 Genocide Studies and Prevention. doi:10.3138/gsp.3.3.375 
information to the enemy. Along the Aegean coast Aivalik stands out as the worst sufferer. According to one report some 70,000 Greeks have been deported towards Konia and beyond. At least 7,000 have been slaughtered. The Greek Bishop of Aivalik committed suicide in despair. The latest account from Trebizond shows the towns along the Black [S] ea are being emptied of their Greek population. From Lyndon S. Crawford, missionary of the American Board [of Commissioners for Foreign Missions] at Trebizond, we have a letter dated July 24, 1917, in which he says the following order came from Turkish army headquarters at Sheishehie [Suşehri]: "By 12/25 July let no Greek man over 16 and under 50 be found in Ordou. Send all such on into the interior. As for the families, we will send further orders later." ... From the Greek minister to the United States, George Roussos, I have a letter, September 21, 1917, in which he says: "... [The Turks] have decided to exterminate the Greek element which is the most important and most numerous in Asia Minor. Under pretext of necessities of war entire populations have been deported. Members of families have been separated. The old, the men unfit for military service and the women were sent into the interior of the country, abandoned without the slightest help and exposed to all sorts of deprivations...."

Jackson's statement was published by a number of newspapers across the country and abroad in an attempt to rally support for the organization. ${ }^{9}$ The range of sources cited provides further documentary evidence and reinforces the value of the statement. Taner Akçam affirms that "the deportation of the Greek population of the Ayvalık region had been carried out on [General Liman] von Sanders's orders, and a great many people had died as a result." 10 The deportation of Greeks from Ayvalık is widely documented, and so no further qualification is necessary. However, Crawford's account, which includes a deportation order issued by Turkish army headquarters, requires closer examination. The original letter can be found in Harvard University's American Board of Commissioners for Foreign Missions collection, and Jackson correctly quotes the Turkish order in his statement. ${ }^{11}$ Crawford's letter, which was addressed to Dr. James L. Barton and copied to the American consul at Trebizond, also describes Greeks and Armenians from more westerly coastal towns fleeing Turkish massacres by traveling at night using caïques to reach safety in Russian-occupied Trebizond. ${ }^{12}$ At least two further factors support or, rather, do not discredit the authenticity of the order. First, at the time the Turkish Third Army was indeed headquartered at Suşehri, Sivas. ${ }^{13}$ Second, the Greek Patriarchate of Constantinople recorded that the deportation of Greek communities in Ordou took place between October 1916 and September 1917. ${ }^{14}$ Furthermore, Crawford's evidence may be judged reliable, despite his death in 1918, in view of later accounts written by his wife, Olive N. Crawford, also a missionary in Turkey, which describe in considerable detail the continued deportation of Greeks. ${ }^{15}$

Professor the Reverend John P. Xenides (1875-1945) served as the GRC'S secretary. Xenides was born in Caesarea, Turkey, and had first-hand experience of the genocide, since he and his family had fled to the United States to escape the 1915 massacres. ${ }^{16}$ He had taught at Marsovan's Anatolia College and Theological Seminary. In a private letter to a colleague, dated 1 October 1917, the secretary of the GRC underlined the increasing threat to the collective existence of the Ottoman Greeks: "According to American Consuls just returned from Turkey some 700,000 Greeks have been deported which means ultimate extermination if the war continues long enough."17 
Later, in a report titled "The Recent Greek Deportations and Other Atrocities in Asia Minor," Xenides offered his interpretation of deportation as a method of destruction and its continued impact on the Greeks:

Deportation means gradual extermination of the people. The deportees are either killed on the way or die through exposure, hunger, disease or exhaustion. For that matter, at least 500,000 Greeks perished between the outbreak of the World War and the Armistice. At present the Greeks in the Black Sea Region and other parts of Asia Minor are undergoing this method of extermination. ${ }^{18}$

Professor Jacob Gould Schurman (1854-1942), president of Cornell University, was appointed honorary chairman of the GRC. Schurman had previously served as US ambassador to Greece in 1912-13. Basile D. Dugundji was vice-chairman, and Abraham E. Kazan, uncle to the famous Greek-American film director and writer Elia Kazan, was treasurer until Rollin P. Grant, president of the Irving National Bank with headquarters in New York City, replaced him in November 1917. Together, these people formed the Executive Committee of the GRC. There was also a Board of Trustees numbering more than forty members (see Appendix A). They were a group of distinguished gentlemen, and at least one woman, and included US ambassador Henry Morgenthau as well as a number of university professors and other eminent figures.

It was not unknown for genocide survivors who escaped Turkey and sought refuge in the United States to join the GRC. Lazaros George Macrides of Trebizond (in Greek,

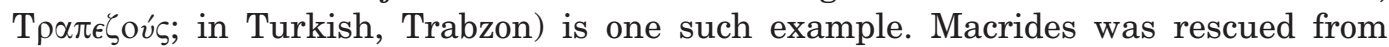
Cotyora (in Greek, Ko $v ́ \omega \rho \alpha$; in Turkish, Ordu or Ordou) on the Black Sea coast by a Russian vessel, along with 2,000 other survivors, in August $1917 .{ }^{19}$ In a statement made public by the American relief organizations, Macrides described some of the practices used in the destruction of the Ottoman Greeks:

Those of us who were between the ages of 16 and 60 were drafted into the Turkish Army. Our women and children and the older men were placed temporarily in homes and orphanages until the opportunity offered to dispose of them in the approved Turco-Teuton fashion, which in this instance turned out to be by wholesale drowning. The unfortunate survivors of the deportation were towed out for several miles into the Black Sea and then calmly dumped overboard, just like so much garbage. None of them survived. ${ }^{20}$

Donations to the GRC came mainly from Greek sources; clergy, organizations, and many individuals all contributed generously. Many Americans also gave both money and service to the cause. Donations were used for relief in regions designated by the GRC. ${ }^{21}$ Mass gatherings proved a useful tool for fundraising and to rally support for the organization. The first gathering of this kind was held on 18 November 1917 in the Amsterdam Opera House on West 44th Street in New York. At the meeting, Henry Morgenthau, former US ambassador to Turkey, told of the treatment of Greeks, Armenians, and other nationalities by the Turks and said that the death from starvation of many in the Christian population, who had been deported and maltreated, was inevitable unless relief was sent speedily. A Greek government minister also spoke, commenting that the Turkish authorities had implemented a general extermination of the Greeks of Asia Minor. Some $\$ 1,000$ in cash was subscribed, and several thousand more dollars pledged, at this meeting alone. ${ }^{22}$

In addition to organizing such meetings, the GRC also published leaflets and booklets, such as Relief for Greeks of Asia Minor and The Tragedy of the Sea of 
Marmora, to draw attention to Greek suffering. ${ }^{23}$ In their publications, the GRC frequently drew a parallel with the Ottoman Armenian experience, appealing to America's long-standing and steadfast sympathy for Armenians in the hope that such philanthropy might also be extended toward the Greeks. The following passage is a typical example of this policy:

The world was shocked with the horrors of Armenian atrocities. Now we hear similar horrors meted out to the Greeks, the most numerous Christian element in Turkey. They are being deported from the coast regions, where they used to live and prosper. They have been deported in large numbers from their homes along the Black Sea coast, the Marmera [Marmara] and the Aegean Sea, suffering and many of them dying from hunger, exposure, hardships and resultant diseases. The world already knows from its application to Armenians that deportation means slavery, untold suffering, exposure, starvation and disease, thus gradual death. Massacres were more merciful as compared with the tortures and horrors of deportation. The Greeks are not massacred at the same rate as the Armenians, but they are forced to move on, move on to regions where no food can be found. The route of their march is strewn with corpses. Deportation proves to be more effective than massacres in making havoc and devastation, but it also gives better opportunities to relief workers and those engaged in life saving. Missionaries and other devoted kind-hearted people are on the spot able and ready to render relief to the deportee. Would you not give a helping hand and send relief to these latest innocent victims of oppression and tyranny.

Thousands have escaped with their lives from the Black Sea coast towns and villages to Trebizond, now in Russian hands. American Consuls and missionaries are ready to render relief to these refugees. Would you not help to make the relief possible?

A quarter of a million of Greek refugees have escaped from Turkey to Greece proper, where they are practically homeless and in urgent need of food and clothes. Scores are dying daily of insufficient food and resultant diseases, especially women and children are in a terrible plight. The Relief Committee for Greeks of Asia Minor, 1 Madison Avenue, endeavors to raise funds for these sufferers. ${ }^{24}$

The American Committee for Armenian and Syrian Relief had been formed in 1915 in response to the massacres and deportations of Armenians. Its name suggests that the organization was principally concerned with the Armenians and Syrians. Talcott Williams, a member of ACASR and also later a member of the GRC, asserted that "the need of relief for the suffering Greeks is as urgent as for the Armenians and Syrians."25 The obvious question is, Why were the Greeks apparently excluded? In practice, they were not. ACASR fundraising, educational, and other documents indicate that this organization did engage in relief for Ottoman Greeks. However, the absence of the word "Greek" in its title may certainly have prompted the creation of a committee that unmistakably spoke for the Greeks, namely the Relief Committee for Greeks of Asia Minor. ACASR eventually became the Near East Relief (NER), an organization of greater scope. According to that organization, "Armenian suffering in Turkey is paralleled, with certain modifications by the experiences of the Greeks."26

In Story of the Near East Relief, James L. Barton, NER chairman, refers to the GRC as a "co-operating" committee. ${ }^{27}$ In fact, the GRC and the NER were intertwined in several ways. To start with, they shared offices at 1 Madison Avenue. A number of members served on both committees, including Henry Morgenthau. Chairman Jackson and at least six other members of the GRC were appointed trustees of the NER in the 6 August 1919 act of Congress that formally incorporated the organization. ${ }^{28}$ Finally, there existed a financial relationship between the two organizations, in that 
any contribution made to the GRC was doubled by the NER. In total, the NER contributed $\$ 250,000$ to the GRC. Thus, $\$ 500,000$ - several million dollars by today's standards-was spent for the relief of Greeks in the Ottoman Empire by the GRC. ${ }^{29}$ At the same time, the NER was also heavily engaged in relief work that included Ottoman Greeks - as is emphasized by how heavily the word "Greece" featured on NER fundraising posters and in other documents. Given the intimate relationship between the two organizations, it is all the more remarkable that not even scant references to the Relief Committee for Greeks of Asia Minor exist in the works of those who have studied and written about the relief efforts in Turkey.

In terms of both mission and operation, it is true that the GRC was a much smaller organization than the NER. Nonetheless, it had strong support from outside the Greek-American community. President Woodrow Wilson sympathized with the plight of the Ottoman Greeks and supported the relief movement:

I am in hearty sympathy with every just effort being made by the people of the United States to alleviate the terrible sufferings of the Greeks of Asia Minor. None have suffered more or more unjustly than they.... I warmly commend the efforts being made by the Relief Committee for Greeks of Asia Minor, to relieve the suffering Greeks of that country, and I bespeak for it the hearty and continued support of the Greeks and all lovers of Greece in America. ${ }^{30}$

Others who expressed their support or gratitude included the Ecumenical Patriarch of Constantinople, various bishops, and leading Greeks in both Greece and Turkey. ${ }^{31}$

On 8 December 1919, the Royal Order of George I was bestowed upon six members of the GRC on behalf of King Alexander of Greece by George Roussos, Greece's ambassador to the United States. The recipients were GRC chairman Frank W. Jackson; treasurer Rollin P. Grant; Dr. Hamilton Holt, editor of the Independent; Dr. Frederick H. Lynch, editor of Christian Work; Prof. Alfred D.F. Hamlin of Columbia University; and Rev. Herbert F. Laflamme of the Interchurch Movement. Through this decoration the Greek government officially expressed its appreciation for the work of the GRC. ${ }^{32}$

In July 1921 the Relief Committee for Greeks of Asia Minor ceased to exist. It handed over its work to the NER, which actively continued the Greek relief effort for several more years. The circumstances in which the GRC came to an end are unclear. One speculation is that the inclusive and increasingly encompassing nature of the larger NER organization now made unnecessary the existence of two committees whose operations were overlapping. After all, by its own admission, the NER had now become "a non-denominational Christian organization ... ministering to the desperate needs of the Armenians, Greeks, Syrians and others, victims of the Great War, in Turkey and nearby regions." 33 However, further research must be completed before we can establish what brought about the end of the GRC. ${ }^{34}$

In any case, this was not to be the end of cooperation between the NER and Greekorientated relief organizations. To name only one example, in the post-Genocide period, when there was an effort to keep alive hundreds of thousands of refugees, orphans, and other survivors, American Friends of Greece, Inc. (AFG), was formed "for aid to Greece and the refugees of the Near East." 35 The NER's Cleveland Dodge, Charles Vickrey, Barclay Acheson, and John Finley, along with many of the other leading officers of the NER, were all active members or officers of AFG, an organization that saved countless Greek and Armenian lives. ${ }^{36}$

The work of the Relief Committee for Greeks of Asia Minor is an important chapter in the history of both the Ottoman Greek Genocide and American philanthropy. 
Unfortunately, material pertaining to the GRC is not housed in one central depository but is dispersed in different archives-personal, organizational, and governmentalthroughout the United States. The same is true for a fair amount of material pertaining to the NER. Therefore, much work remains for researchers interested in constructing a more complete picture of the GRC's work in saving Greek lives during the final years of the Ottoman Empire.

\section{Acknowledgments}

Allen Odian, Stanford University; Marisa Bourgoin of Archives of American Art, Smithsonian Institution; Wayne D. Weber of the Billy Graham Center Archives, Wheaton College; and Bridget Keown of the Houghton Library, Harvard University, all provided me with copies of relevant material from their institutions' collections. Abraham D. Krikorian read a draft of this paper before publication. I am indebted to all mentioned.

\section{Notes}

1. “Turks Are Backed by Germany," Warren Evening Mirror, 17 October 1917, 1.

2. John P. Xenides, The Greeks in America (New York: George H. Doran Co., 1922), 115-16. For an account of the relief work see "A Recent Letter from Salonica to the Secretary of the Greek Relief Committee," letter from W.C. Cooper (1 December 1917), Gertrude V. Whitney Papers, Archives of American Art, Smithsonian Institution. For a list of other similar relief committees see Louis P. Cassimatis, American Influence in Greece 1917-1929 (Kent, OH: Kent State University Press, 1988, 131).

3. "Relief for Greeks of Asia Minor," Gertrude V. Whitney Papers, Archives of American Art, Smithsonian Institution.

4. Letter, John P. Xenides to H.P. Whitney (4 June 1918), Gertrude V. Whitney Papers, Archives of American Art, Smithsonian Institution.

5. Ibid.

6. Letter, Xenides to Jacob Gould Schurman (1 October 1917), Box 3, Folder 5, Jacob Gould Schurman Papers, Cornell University Library.

7. "Frank W. Jackson," New York Times, 11 March 1955, 25.

8. "Turks Are Backed by Germany," Warren Evening Mirror, 17 October 1917, 1.

9. See, e.g., “Turks Slaughter Christian Greeks," Lincoln Daily Star, 19 October 1917, 7; "Greek Persecution in Turkey," Scotsman, 6 November 1917.

10. Taner Akçam, A Shameful Act: The Armenian Genocide and the Question of Turkish Responsibility, trans. Paul Bessemer (London: Constable, 2007), 285.

11. Letter, Lyndon S. Crawford to Rev. James L. Barton (24 July 1917), Houghton Library, ABC 16.9.3, vol. 41, Western Turkey mission, 1910-1919, v. 3, A-C (microfilm reel 630).

12. Ibid.

13. Edward J. Erickson, Ordered to Die: A History of the Ottoman Army in the First World War (Westport, CT: Greenwood Press, 2000), 136.

14. Greek Patriarchate, Persecution of the Greeks in Turkey 1914-1918 (Constantinople: Greek Patriarchate, 1919), 126.

15. See, e.g., "Report on the miserable condition of Greeks due to the deportations," letter, Mrs. Crawford of Trebizond to Dr. William Peet (25 April 1922), British Foreign Office Archives, FO 371/7878.

16. "Rev. John Xenides, Pastor 17 Years, 75: Minister of Greek Evangelical Church Dies—Fled the 1915 Massacre in Turkey," New York Times, 8 June 1945, 19.

17. Letter, Xenides to Schurman (1 October 1917).

18. John P. Xenides, "The Recent Greek Deportations and Other Atrocities in Asia Minor" (1921), US National Archives, Files of the Department of State, NA 867.4016/432. 
19. R. Lavinia Hanton, "Bombarding Ships Rescue 2,000 Greeks," New York Times, 7 April 1918, 48. This report was later reproduced by the GRC and distributed as a leaflet along with fundraising material.

20. “1,000,000 Greeks Killed?” New York Times, 1 January 1918, 15.

21. Xenides, Greeks in America, 116-17.

22. "Hope America Will Aid Greeks in Asia Minor," New York Times, 19 November 1917, 4.

23. The latter is available for download at http://www.greek-genocide.org/books.html (accessed 15 September 2008). For an example of an illustrated publication see Relief for Greeks of Asia Minor, Gertrude V. Whitney Papers, Archives of American Art, Smithsonian Institution. This particular document contains imagery of "hungry and homeless [Greek] refugees."

24. Ibid.

25. "Greek Deportations: The Needs of the Latest Victims of Turkish Cruelty," New York Times, 8 October 1917, 10.

26. Near East Relief [NER], Speakers' Handbook of American Committee for Relief in the Near East (New York: NER, c. 1919), 33.

27. James L. Barton, Story of Near East Relief (1915-1930): An Interpretation (New York: Macmillan, 1930), 63. It should be noted that Barton's work was "a history ..." not "the history..."; in other words, the definitive account of the work of the NER has yet to be written.

28. Ibid., 432.

29. Xenides, Greeks in America, 116.

30. NER, Speaker's Handbook of American Committee for the Relief of the Near East (Formerly the Committee for Armenian and Syrian Relief) (New York: NER, c. 1919), 9. NER published several speakers' handbooks during this period; this one should not be confused with the one cited in note 26 above.

31. Xenides, Greeks in America, 116.

32. "Greek Honors for Board: Ambassador to Decorate Members of Asia Minor Relief Committee," New York Times, 8 December 1919, 15; "Greece Honors U.S. Relief Workers," New York Times, 9 December 1919, 35.

33. NER, Near East Relief: Syria-Palestine-Area (Beirut: NER, c. 1925).

34. Any effort to ascertain how the GRC came to an end must begin with an examination of the correspondence between committee members (listed in Appendix A). In fact, the papers of the committee members, now often housed in university library collections, would be the first port of call for any further research. For example, the papers of D. Callimachos, housed at the University of Minnesota, contain a wealth of material not only on the GRC but also on other committees of the same period.

35. American Friends of Greece was established in Washington in 1923 with Dr. Edward Capps, former minister to Greece, as president. For more information on AFG see Louis P. Cassimatis, American Influence in Greece 1917-1929 (Kent, OH: Kent State University Press, 1988), 260.

36. Letter, Edward Capps to Petros Titanis (12 May 1924), Papers of Demetrios P. Callimachos, 1879-1963, Greek American Collection, Immigration History Research Center, University of Minnesota, Box 7, Folder 39.

37. Telegram from Athens, Relief Committee for Greeks of Asia Minor, Gertrude V. Whitney Papers, Archives of American Art, Smithsonian Institution.

38. See, e.g., William H. Hall, Reconstruction in Turkey: A Series of Reports Compiled for the American Committee of Armenian and Syrian Relief (New York: [ACASR], 1918), 39.

39. Tessa Hofmann, "German Eyewitness Reports of the Genocide of the Armenians, 1915-16," A Crime of Silence: The Armenian Genocide, 61-92 (London: Zed Books, 1985), 73; Aris Kyriazis, Palinnostisi stis Glykes Patrides 1918-22 [Repatriation to Sweet Homelands, 1918-22] (Athens: Phanarion, 2003), 26. 
40. Greek Ministry for Foreign Affairs, Persecutions of the Greek Population in Turkey since the Beginning of the European War: According to Official Reports of Hellenic Diplomatic and Consular Agents (London: Constable \& Co., 1918), 25-26.

\section{Appendix A: Greek Relief Committee Board Members}

\section{Executive Committee:}

Chairman: Frank W. Jackson*

Honorary Chairman: Jacob Gould Schurman

Vice-Chairman: Basile D. Dugundji

Secretary: John P. Xenides*

Treasurer: Abraham E. Kazan (resigned November 1917), Rollin P. Grant

Board of Trustees:

Mr. Nicholas P. Antoniades, merchant

Mr. Michael B. Atheneos

Mr. Athanasios D. Barouxakis, merchant

Rev. Prof. Hugh Black, Professor of Practical Theology, Union Theological Seminary

Rev. Dr. Robert G. Boville, Baptist clergyman, founder and director of the Daily

Vacation Bible School movement

Rev. Dr. Arthur J. Brown, ${ }^{*}$ secretary of the Presbyterian Board of Foreign Missions

Prof. Howard Crosby Butler, Professor of the History of Architecture, Princeton University

Rev. Prof. Demetrios Panos Callimachos, journalist, priest, author, professor, and editor of the National Herald

C. Carusos

N. Cindaxopoulos

Dr. Sophocles Dadakis, physician, president of the Pan-Hellenic Union

Prof. Raphael S. Demos, Harvard University

Dr. Samuel Train Dutton, ${ }^{*}$ secretary of the American Committee for Armenian and Syrian Relief

Prof. Henry Pratt Fairchild, American sociologist

Prof. Alfred Dwight Foster Hamlin, Professor of the History of Architecture, Columbia

University

Dr. William I. Haven, ${ }^{*}$ general secretary of the American Bible Society

Dr. Hamilton Holt, editor of the Independent

Mr. Abraham E. Kazan, pioneer organizer of housing cooperatives in the United States

Eurypides Kehaya

Rev. Herbert F. Laflamme, Interchurch Movement

Dr. Walter Laidlaw, Federation of the Churches

Prof. Abby Leach, Vassar College

Mr. Michael Litsas, merchant

Mr. B.A. Livieratos

Mr. C.D. Logothetis

Dr. Frederick Henry Lynch, ${ }^{*}$ editor of Christian Work

Mr. Nicholas E. Marcoglou, merchant

Mr. Henry Morgenthau, ${ }^{*}$ former US ambassador to Turkey

Mr. George D. Nicholas

Dr. Frank Mason North, ${ }^{*}$ minister of the Methodist Episcopal Church

Mr. Theodore Photiades, merchant

Prof. Aristides Phoutrides, Harvard University

Mr. John C. Pialoglou, tobacco merchant

Prof. Chandler Post, Harvard University

Mr. John N. Poulides, tobacco merchant 
Prof. Theodore Leslie Shear, Professor of Classical Archeology, Princeton University

Prof. John Gabriel Stateropoulos, Professor of Chemistry, Columbia University

Mr. John D. Stephanides, lawyer

Petros P. Tatanis, publisher of the National Herald

M. Theodoropoulos

Dr. George William Tupper

Rev. Dr. William H. Van Allen, rector, Church of the Advent, Boston

Dr. Talcott Williams*, Turkish-born journalist

* Also connected with the American Committee for Armenian and Syrian Relief and/or its various successors.

\section{Appendix B: Sample Archival Document}

To encourage researchers to explore GRC material and to illustrate the type of material available from the perspective of documentation of the Greek Genocide, I append the following document. This telegram was written in 1918 and sent from Athens to GRC headquarters in New York City:

According to the testimony of Mohammedan prisoners of war in Salonica made to the Entent [Entente] authorities there, the Greeks in Turkey are undergoing the worst blow since the fall of Constantinople. This takes place in a threeforld [threefold] way. First, in General Moblization [Mobilization]. Second, Commandeering. Third, Deportation. Since the beginning of the war to the end of 1917 these Mohammedan prisoners state that more than two hundred thousand Greeks between the ages of fifteen and forty eight have been drafted into the Turkish army. Thousands of these have died as a result of ill treatment, hunger and epidemics. More than five hundred thousand Greeks have been deported from Thrace into Asia Minor. With the exception of the Greek population of Smyrna, Constantinople and a few other towns, all the Greeks underwent untold suffering, exile, tortures and epidemics. Many were slaughtered in the interior of Asia Minor, and the survivors are in a terrible plight. Women are sold as slaves, men are forced to become Mohammedans and the Military officials declare openly everywhere that no Greek will be allowed to live in Turkey unless he becomes a Mohammedan. The property confiscated from the Greeks is worth five billions. Many of these Mohammedan prisoners relate that they saw with their own eyes men from Aivali and many other large cities who were working as slaves in rags and begging for a piece of bread. They say Smyrna is melting like wax. There are from forty to fifty deaths daily among the Greeks as a result of hunger, weakness and epidemics. Two hundred families have been deported from Tatavla in Constantinople. The streets in larger cities are full of Greek orphans, half naked begging for bread in spite of the fact that the Turkish authorities tear them from the bosoms of their parents and circumcise them. ${ }^{37}$

Incidentally, the deportation of Greek families from Tatavla (in Greek, T $\alpha \tau \alpha u ́ \lambda \alpha$; in Turkish, Kurtuluş) is an important assertion, because for some considerable time we have been led to believe that the Greeks and Armenians of Constantinople were not subjected to the perils of deportation. ${ }^{38}$ Only in recent years has a corrective been provided. $^{39}$ Of course, the 24 April 1915 arrest and deportation of Armenian intellectuals has always been widely known-unlike its precursor, the 8 March 1915 arrest and deportation of 200 Greeks from the same city. ${ }^{40}$ 